Between Art Nouveau and the Avant-Garde: The Personal (Ego) Network of Ivan Meštrović and the Map of Critical Reception of His Work during the

\title{
1910s
}

Prančević, Dalibor

Source / Izvornik: Modern and Contemporary Artists' Networks. An Inquiry into Digital History of Art and Architecture, 2018, 38 - 62

Book chapter / Poglavlje u knjizi

Publication status / Verzija rada: Published version / Objavljena verzija rada (izdavačev PDF)

https://doi.org/10.31664/9789537875596.03

Permanent link / Trajna poveznica: https://urn.nsk.hr/urn:nbn:hr:254:591141

Rights / Prava: In copyright/Zaštićeno autorskim pravom.

Download date / Datum preuzimanja: 2023-04-26

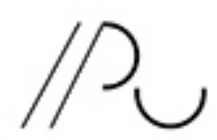

INSIIIUT ZA POVIJEST UMJETNOSI
Repository / Repozitorij:

PODEST - Institute of Art History Repository

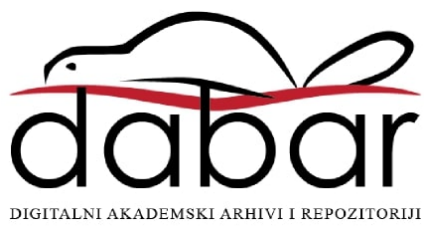


Between Art Nouveau and the Avant-Garde: The Personal (Ego) Network of Ivan Meštrović and the Map of Critical Reception of His Work during the 1910s

DOI: https://doi.org/10.31664/9789537875596.03
INTRODUCTORY NOTES: AN INTERPRETATION BETWEEN

THE TRADITIONAL AND THE DIGITAL ART HISTORY

One of the most significant Croatian sculptors in the 20th century, Ivan Meštrovic (1883-1962), affirmed himself as a sculpto in the public eye mostly "ex-territorially", i.e. outside of his homeland (III. 1)..$^{58} \mathrm{His}$ starting point was Vienna, the city with a distinctive cultural climate where he completed his formal academic education (a three-yea degree course in sculpture and a two-year degree course in architecture). He was also a member of the Association of Visual Artists Austria - Secession and a very active participant in the exhibitions held by the Association. ${ }^{59}$ In this text, his solo-exhibition at the of Vienna Secession in 1910 is taken as the starting point of the period under scrutiny, which extends to the end of the First World War and the artist's return to his homeland, enveloped in a brand new socio-political climate, at the beginning of the 1920s.

Wars always provide an interesting context for observing and analysing artists' behav iours and creative outputs, and the same applies to Ivan Meštrović in the context to the Balkan Wars and the First World War, as well as to the Second World War at a later point in time.

58 The most comprehensive study on the life and art of Ivan Meštrović was written by Duško Kečkemet, who dedicated a significant portion of his career to this artist and interpreting his works. See: Duško Kečkemet, Život Ivana Meštrovića (1883 1962 - 2002), vol. I and vol. II (Zagreb: Školska knjiga, 2009)

59 About the period that Ivan Meštović spent in Vienna, see: Irena Kraševac, Ivan Meštrović i secesija: Beč - München - Prag (Zagreb: Institut za povijest umjetnosti, Fundacija Ivana Meštrovića, 2002). resting phenomenon not only from the perspective of the visual art production, but also from the perspective of setting up a wide network of acquaintances, especially with prominent individuals from the cultural and political arena. His politica engagement was most pronounced during the First World War, but his inclination to establish politically affiliated contacts was a constant in the decades to come, until the end of his life. This political engagement was of great importance to the artist, as attested in his first book of memoirs, first published abroad, in Buenos Aires in 1961, and then, posthumously, in his homeland in 1969. We are, of course, referring to the book Memories of Political People and Events (Uspomene na političke ljude događaje), where he recounted the events spanning from his move to Belgrade in 1904 to his move to the United States in $1947 . .^{60}$ is interesting to note that there are almost no protagonists from the art world featured in this book; Meštrović mentioned them at least some of them - on other occasions. This book represents an outstanding contribution to political history, provided via autobiographical records and notes. However, Ivan Meštrović never considered himself to be a professional politician - he adamantly refused to be classified as such - and he used to point out that his vocation was exclusively that of an artist.

This text attempts to approach the interpretation of Ivan Meštrović's activities by using entirely different tools than those usually implemented in art historical practice. I will show how to implement a quantitative analysis, more suitable - as hitherto perceived - to other disciplines, in the domain of art history research. The challenge

60 Ivan Meštrović, Uspomene na političke ljude i dogadaje (Zagreb: Matica hrvatska, 1969). 
is thus even greater because this kind of research usually deals in texts and textual explications, that is, they are, in most regards, logocentric. Indeed, from the very beginning, the question arises of how to reconcile the reflexive nature and approach to research in humanities - always verging on ambiguity, fluid, floating - with the exact and measurable data which quantitative analysis, as well as the new technology, necessitate. Actually, how do we even in troduce quantitative analysis - and digital tools - into the field of art history, mostly perceived as being reflexive? Is there an antagonistic relationship between "traditional" and "digital" art history?

Perhaps the answer to this and similar questions can be found in an optimistic note in the article "Debating Digital Art History", where Anna Bentkowska-Kafel analyses this specific relationship. ${ }^{61}$ Namely, the autho claims that the attribute digital has a mere provisional and temporary character, and that it will become completely irrelevan and without any precise demarcation in the near future. So, only the umbrella term of art history will remain, of course, with all the changes and turns in the discipline ushered in by technological advancements and the implementation of new techniques. Nobody will even think in terms of an antagonistic relationship but about the critical moment which will have marked the redefining poin of transition, that is, the implementation of new methods in research defined by a temporal format and technological context. We will attempt to demonstrate such a coexistence - or a hybrid - of traditiona and digital art history methods by interpreting Ivan Meštrović's oeuvre and worldviews, that is, his global critical reception.

61 Anna Bentkowska-Kafel, "Debating Digital Art History," International Journal III. Ivan and Ruža Meštrović in the company of his younger sister Danica (fare left) (Family Archive Kaštelančić, Klein, Kundi, courtesy of Sabina Kaštelančić)
IVAN MEŠTROVIĆ'S PERSONAL NETWORK. NETWORK

ANALYSIS A FRAGMENT OF

LINEAR STORYTELLING

Right at the beginning, it should be noted that Ivan Meštrović's social network was reconstructed herein based exclusively on his written correspondence, archived in Atelie Meštrović in Zagreb (Fig. 1).

This is a special archival fund, stored as the property of Mate Meštrović. ${ }^{62} \mathrm{~A}$ total of 606 letters have been processed, with a focus on the period from 1910 to 1920. The basic information about the letters, as well as content excerpts, have been entere into the digital database Croatian Artists Networks Information System (CAN_IS) that stems from an intensive interdisciplinary work on a five-year research project Modern and Contemporary Artist Networks, Art Groups and Art Associations: Organisation and Communication Models of Artist Collaborative Practices in the 20th and 21st Century. Furthermore, the visual depiction of Meštrović's social network was created via software visualization tools which were integrated into the database.

As to be expected, this type of a reconstruction is not ideal. Namely, a large portion of the epistolary records lack a specified timeframe that cannot be inferred from its contents, so this analysis should not be tak en at face value. However, it certainly does pave the way for future interpretations and will be complemented by each subsequent insight into the personal and official correspondence of Ivan Meštrović, stored in institutional or private archives. Nonetheless,

62 Meštrović's Correspondence, Meštrović Atelier Archives, Archived letters (hereinafter: AAM, Zg, Pup). The letters are in the property of Mate Meštrović who was kind enough to grant his permission to us to use and inspect them. 
Fig. 1

Personal social network of Ivan Meštrović between 1910 and 1920, network visualization based upon data extracted from his personal correspondence based on this sample, we can clearly differentiate the key layers of social protagonists who are mutually intertwined and reflect the character of Ivan Meštrović and his collaborative-communicative disposition. The artist's network is not one-dimensional - as the rarely are! - and includes the protagonists not only from his intimate-familial and cultural-artistic surrounding, but also from the historical-political context since, during the First World War, Meštrović became engaged in a concrete - or we might even define it as nation-building - political activism.

Despite reconstructing the network based solely on the archived correspondence from one source, many key relationships with individuals whose letters were not contained within could be inferred. For example, especially important are the connections that Meštrović forged with the members of the ruling political class, such as the members of the Serbian royal family Karađorđević since the very beginning of their rule in 1903. In addition, by holding important exhibitions and capturing the attention of experts and the wider public, Ivan Meštrovic also met other royalty to whom he acted as a guide at the exhibitions, as he did for the Italian King Victor Emmanuel III of Savoy and his wife Jelena of Savoy, daughter of the king of Montenegro Nikola I Petrović-Njegoš, at the International Fine Arts Exhibition in Rome (1911).63 Furthermore, the Grafton Galleries exhibition held in London in 1917, which he prepared with Mirko Rački and Toma Rosandić, was inaugurated by a member of the British royal family, Princess Patricia of Connaught. This omission, regarding domestic or internationa relations, also equally applies to numerous other protagonists from artistic and wide cultural circles.

First of all, we should address what socia

etwork analysis means and how it sheds ist on certain issues related to art history. When we refer to social network analysis, this usually implies two basic approaches: the sociocentric and the egocentric The egocentric approach anchors a social network on an individual agent and observes the forms of social relations that emphasize the personal nature of society. The sociocentric approach, on the othe hand, relies on the principles and structura connectivity of the network as a whole..$^{64}$ is apparent that Ivan Meštrović's social network is of a personal - or in other terms - of an egocentric type. It cannot be conceived as a spatially delineated structure, in the sense of understanding the society itself as a territorially defined entity, but rather as a set of connections with the other actor who are part of the network. These are, of course, several kinds of connections (familial, friendship-based, cooperative, etc.) which belong to different geographical longitudes and latitudes, that is, to different socio-political and, in general, historical circumstances.

Ivan Meštrović's personal network - at least when it comes to its cultural-artistic and historical-political layer - is decidedly pragmatically motivated, that is, it is structured around organizing severa key exhibitions, not just in regard to his personal affirmation, but generally in re gard to the art history of this region and the political-ideological programme that permeated these exhibitions. There is no doubt that Meštrović's critical art narrative was directed against Austria and, in that sense, he was a prominent ideologue of one art association very significant for the

64 More on the differences between sociocentric and egocentric networks, see: John Scott, Social Network Analysis:

63 Meštrović, Uspomene na političke ljude A Handbook (London: Sage Publications, i događaje, 18-19.
2000), 69-81. 
1910, Stevan Todorović, the president of the Rome Exhibition Committee, informed Ivan Meštrović that his participation was approved, as well as the unrestricted exhibition space, while all the other artists that Meštrović mentioned would have to apply on their own with all the necessary information. ${ }^{68}$ The greatest success was achieved by Ivan Meštrović himself, winning the Grand Prix for Sculpture and participating, as the data extracted from the CAN_IS database show, in all the segments of the exhibition's realization: maintaining correspondence with the members on different committees, cooperating with the architect Petar Bajalovic on devising and assembling the exhibition pavilion, undertaking motivational activities in order to prompt the artists to participate in the exhibition, and so on

Of course, the consequences were far-reaching. The success in Rome had also prompted the creation of the entire network of Ivan Meštrović's acquaintances with protagonists from the art and wider intellectual circles. It suffices to point out the prominent individuals such as the sculptor Leonardo Bistolfi, the sculptor Giovanni Prini and his wife Orazia Belpito Prini, Sibilla Aleramo (a famous writer who published a comprehensive article on Meštrović's works in the magazine Lettura), the poet Vincenzo Cardarelli, and many others. It would not be deemed impertinent to mention that the real moderator of Meštrović's social life was his wife Ruža who, in part, managed the correspondence due to her knowledge of several world languages. She, for example, exchanged letters with Sibilla Aleramo, who sent her the French translation of her acclaimed novel A Woman at Bay (Una donna). The first contact with Vittorio Pica, that is, Ivan and Ruža's correspondence with the director of the art journal Emporium, prom-

68 Meštrović's Correspondence: Todorović, Stefan, ident. 861 (AAM, Zg, Pup). possible enfants terribles, and often, to gain an enemy, there is nothing worse than, prompted by the burning power of friendship, to give them what they ardently desire. Unfortunately, I had a bitter experience with Anglada and with some other artists, and I would not want the same to happen with my friend Meštrović... ${ }^{70}$

The qualifier "friend" which defines the character of the relationship that Meštro vić had with Pica and his wife Ana, whom he portrayed, is especially interesting. In any case, this collaboration turned out to be a success.

In addition to sculptures inspired by folk traditions and idea of Yugoslavism, at the 1914 Venice Biennale, the artist also exhibited the wooden model of the Vidovdan Temple, along with some other works inspired by religious motifs. The poet and prose writer Ettore Cozzani devoted an entire issue of L'Eroica magazine to Meštrović and his work, which had a resounding effect in the Italian and European intellectual circles. Due to the archived letters, it is possible to gain insight into the compelling network of Ivan Meštrović's relationships with prominent protagonists from the Italian intellec tual milieu at that time. These contacts were largely epistolary in character, but there were also meetings and conversations held outside the confines of written correspond ence. Although many of these contacts were prompted by the cultural and artistic context, some of them belong to a more intimate and emotional sphere, in the sense that close friendships had been maintained throughout their lives and passed onto their descendants, for example, the one with the Signorelli family.

On the other hand, Ivan Meštrović's politica engagement would gain momentum after

Talijanska pisma Ivanu Meštroviću [Italian

Letters to Ivan Meštrović] 1911 - 192

(Zagreb: Globus, 1987) ion in Sarajevo and the beinning of the First World War. At the time of the Sarajevo assassination, Meštrovic was in Venice. After a short stay in Split, Meštrović went to Italy again to avoid being arrested. Namely, the Austrian authorities had arrested a large number of politically engaged individuals to halt their political activities and circumvent any problems that might have otherwise arisen.

Not only Ivan Meštrović, but also Ante Trumbić and Frano Supilo lived abroad, and this immigration enabled political activity. Thus, the historian Norka Machiedo Mladinić points out that: "Ivan Meštrović's firs contribution to the assembling of the expats at the beginning of the First World War consisted of encouraging our people to leave their homeland and move to then neutral Italy. Trumbić, Supilo and Meštrović met in Venice. The main focus of their efforts was to achieve the liberation of Slovenes, Croats and Serbs from Austro-Hungary and their unification with Serbia and Montenegro in one country." ${ }^{\prime \prime 1}$ Thus, it was at that time tha the idea of establishing a political body - the Yugoslav Committee - in charge of carrying out the project of the Yugoslav unification was conceived..$^{72}$ Numerous letters and data from CAN_IS database refer to the work of this entity and its actors, providing a detailed account of the historical-political layer of Meštrović's social network.

It is important to note that not a lot of people from the art circle were as exposed to the public as Ivan Meštrović was. That is why he was such a valuable asset in initiating first contacts and conversations

71 Norka Machiedo Mladinić, "Prilog proučavanju djelovanja Ivana Meštrovića u Jugoslavenskom odboru," Casopis za suvremenu povijest, vol. 39, no. 1 (June 2007), 135.

72 The Yugoslav Committee was founded in Paris, on 30 April 1915 
with various political entities and delegations. For example, due to his connections, Meštrović was able to reach the Serbian emissary in Rome, Ljubomir Mihajlović, and inform him about the intention to estab lish the organization of Yugoslav expats. Consequently, via Mihajlović, the trio Supilo-Trumbić-Meštrović were granted an audience with the French (Camille Barrère) English (Sir James Rennell Rodd) and Russian (Anatolij Nikolajevič Krupenski) em issaries to Rome, at the end September, in $1914 .^{73}$ They delegated the plan of the South Slavic unification to their respective governments. However, their work could not continue in Italy due to the Italian territorial pretensions aimed towards the east coast of the Adriatic, so they relocated it to London, the centre of Allied diploma cy. In London, there was only a handful of cultural workers and intellectuals familia with the programme: Robert Seton-Watson (a scholar in Slavic studies and Ivan Meštrović's close friend, who was portrayed by the artist and gifted some of his works), Wickham Steed (editor of the Foreign Policy section in The Times, also portrayed by Ivan Meštrović) and Arthur Evans (a renowned archaeologist who was a great admirer of Ivan Meštrović's work)

One way or the other, the point of direct contact between the political and the artistic engagement were Meštrović's exhibitions held primarily in London, during the First World War. The first one was held in the Victoria \& Albert Museum in 1915 and had strong political implications affirming the Anti-Austrian sentiment embodied through the staging of the Kosovo Cycle and dis playing the model of the Vidovdan Temple.

73 Machiedo Mladinić, "Prilog proučavanju djelovanja Ivana Meštrovića u Jugoslavenskom odboru", 135-36.

74 For a comprehensive analysis of famous Grafton Galleries, which was also marked by a pronounced political stigma but without an explicitly political narrative footing, because the artist did not display his, so-called, Heroic Cycle but works inspired by religious themes and portraits that he made in London (III. 3).

Both exhibits are very interesting because they attest to the extremely wide social circle that Ivan Meštrović established in the UK at the time.$^{75} \mathrm{His}$ stay in the UK had resulted in the relationships forged with some of the most prominent cultural and social protag onists. The solo-exhibition in the Victoria and Albert Museum in London had ensured Ivan Meštrović a prestigious position in English society. The artist made a number of acquaintances and social connections with high-profile individuals in London, whom he often portrayed. He made portraits of Lady Maud Cunard and Sir Thomas Beecham who were associated with the avant-gard theatre, in particular, with Sergei Diaghilev's Ballets Russes. He also made a portrait of Eugenie Errázuriz, who was colloquially known as "Picasso's Other Mother", thus succeeding Gertrude Stein. Furthermore, he made a portrait of Tony Gandarillas, a controversial diplomat, and his wife Juan Edwards. Tony Gandarillas was the nephew \& Albert Museum and its reception, see: Elizabeth Clegg, "Meštrović, England and the Great War," The Burlington Magazine, no. 144 (December 2002), 740-51; and Dalibor Prančević, "Odjek Ivana Meštrovića u Velikoj Britaniji nakon izložbe u Victoria \& Albert Museumu," in Zbornik II. kongresa hrvatskih povjesničara umjetnosti (Zagreb: Institut za povijest umjetnosti, 2007), 395-403. 75 More on the exhibition at the Grafton Galleries in London, see: Dalibor Prančević, "Sculpture by Ivan Meštrović at the Grafton Galleries in 1917: critical an social contexts," Sculpture Journal 25, no. 2 (2016), 177-192. 
of Eugenie Errazuriz and also associated with the avant-garde circle of artists in Paris and London. Meštrović was greatly aided by his wife Ruža in these social interactions.

\section{RUŽA MEŠTROVIĆ AND}

HER SOCIAL CAPITAL

Of course, there is a strong network connection between the two spouses, the one that is not based solely on emotional grounds, but one that is also social, because it is evident that Ruža occupies a prominent position in the articulation of Meštrović's social contacts. We should take note of one anecdote which attests to Ruža Meštrović's remarkable resourcefulness and social competence, the kind that promotes dialogue on equal terms and balances out the differences that arise from one's social status or public recognition, but also to her youthful vehemence.

When Ruža and Ivan first went to meet Rodin, he returned the business card on a plate with 5 francs, because he thought that the young sculptor had come to ask him for something. Ruža found her bearings and return 10 francs to Rodin. ${ }^{76}$

Although, in the beginning, a large part of Ruža Meštrović's social network was defined by the artistic and social status of her husband and the general interest in his fine artworks that would soon change. Namely, Ruža was also engaged in creative artwork, producing a number of sculptural portraits at the time, and could discuss at length not only art in general but also the methodology of the sculpting process. For example, she portrayed her

76 Vesna Barbić's record of the conversation with Tvrtko Meštrović (1925-1961), Ivan Meštrović's eldest son. See: University of Notre Dame Archives, Notre Dame, Indiana 46556, Ivan Meštrović Papers, 1924-1962. husband's correspondents, such as the writers o Ćipiko and Vice lljadica. She could, therefore, be a very interesting conversationalist to various participants in the social sphere. Ruža would soon begin to make her own social connections from which arose her own social ego network and social capital.

In visualizing Ivan and Ruža Meštrović's contacts, it is evident that some names are only connected to Ruža. For instance, especially interesting are her hitherto unexplored conacts with the protagonists from the activist and suffragist enclaves. In that regard, we should mention Evelina Haverfield, who often took part in the suffragette protests. During the First World War, Evelina participated in the women's humanitarian aid and relief efforts in Serbia, and closely cooperated with the Scottish suffragette and renowned doctor Elsie Inglis, spending some time with her in Serbia. Tellingly, Ivan Meštrović made a posthumous portrait of Elsie Inglis in 1918. Ruža Meštrović's personal network became notably emancipated through her engagement in humanitarian activities, for example, via a charity tea party, that is, a concert that she organized in London in early 1916. It was a multifaceted event with the aim to present the richness of the cultural life and folk traditions, predominantly related to Serbia, for which voluntary donations were collected. Similar humanitarian events were also organized in Rome, for example in Villa Medici in November 1914, with Ivan Meštrović illustrating the programme's cover. ${ }^{77}$ Many high-profile protagonists from London's social life participated in preparing and promoting Ruža's event in London. For example, Lady Helen Primrose wrote in high praise of the event's organization and sent the money she, herself, raised from ticket sales. ${ }^{78}$ The initiative of the writer and

77 Milačić, Talijanska pisma Ivanu Meštroviću, 6.

78 Meštrović's Correspondence: Primrose, the artist Muirhead Bone's wife, Gertrude Bone, who had just completed one of her children's books, and who wrote to Ruža Meštrović how she would gladly donate the book's profits to helping Serbian children can be examined within the same contextual framework. ${ }^{79}$ Alice S. Green also offered to help with the ticket sales and donated to the cause. ${ }^{80}$ Based on the archived letters it is obvious that Ruža Meštrović put in a lot of effort in organizing this charitable event thus inviting the famous Vivian Edwards to perform her solos and recitals. ${ }^{81}$ However, Edwards was unable to participate due to her health, but expressed hopes that, despite everything, she would be able to visit Ruža's "Serbian Tea Room". Based on the archived correspondence, it is evident that Vivian Edwards was on good terms with Ivan Meštrović and Dimitrije Mitrinović. Furthermore, Ruža's cooperation with Anan da Coomaraswamy, the cultural worke who ardently advocated for the reception of Indian culture and art in the West, is particularly interesting. ${ }^{82} \mathrm{He}$ was friends with prominent artists of the time, such as sculptors Jacob Epstein and Eric Gill, as well as many others. He was also friends with the Countess Sybil of Rocksavage, to whom Ruža sent an invite to the concert. Coomaraswamy's participation in the whole event was undoubtedly important because he sent Ruža the draft of the programme for corrections. He noted that, upon printing the programmes, Ruža should make a list of addresses where the programme was to

Helen, ident. 707 (AAM, Zg, Pup)

79 Meštrović's Correspondence: Bone,

Gertrude, ident. 137 (AAM, Zg, Pup).

80 Meštrović's Correspondence: Green,

Alice, ident. 338 (AAM, Zg, Pup)

81 Meštrović's Correspondence: Edwards,

Vivian, ident. 270 (AAM, Zg, Pup).

82 Meštrović's Correspondence: Cooma-

raswamy, Ananda, ident. 205 (AAM, Zg, Pup) be delivered, that is, that the printing bil was to be sent directly to him.

Indeed, this was just one of the event that contributed to the spreading of Ruža Meštrović's ego network, as attested by the data from the CAN_IS database and the accompanying visualizations. In addition, Ruža and Ivan were invited to socia gatherings by many prominent hostesses of social salons in London, such as Lady Maud Cunard, Baroness Gladys Swaythling, Clara

C. Bergheim (who was connected with the pianist Arthur Rubinstein and the violinist Eugene Ysaÿe), and many others.

The data collected in the CAN_IS database - focusing on the correspondence dated between 1915 and the first half of the 1916 - and the accompanying visualization tools, make it possible to discern the value of social capital wielded by Ivan and Ruža Meštrović, but also the physiognomy of Ruža's distinct network that would become increasingly emancipated in the years to come. Ruža mobilized that network, in it full capacity, when she started living alone after a severe marriage crisis and divorce that ensued in the mid-1920s.

IVAN MEŠTROVIĆ AND THE SPATIAL DIMENSIONS OF HIS CRITICAL FORTUNE

Ivan Meštrović is one of the few artists from this region whose presence on the European art and the cultural scene, in general, was particularly noted. The various contextual frameworks in which he embedded his art, especially the political one, articulated just before and during World War I, contributed to this public standing At this point, we should also mention the importance of large exhibition projects, organized in European cities, in which he participated - either individually, or collectively. Even in those cases where he ex hibited his work alongside other artists, his 
dominance was without question, as can be seen in the written reviews and critiques that followed these exhibitions.

We should thereby focus on several exhibition projects by Ivan Meštrović, within the given timeframe, and which proved to be important geographical markers and platforms around which the written reviews and newspaper articles about the author revolved: Vienna (XXXV Exhibition of the Vienna Secession, 1910), Zagreb (Meštrović-Rački, 1910, and Despite the Unheroic Times, 1910), Rome (the International Fine Arts Exhibition, 1911), Venice (Biennale, 1914), London (Solo-exhibition in the Victoria and Albert Museum, 1915, and Exhibition of Serbo-Croatian Artists: Meštrović, Rački, Rosandić in the Grafton Galleries, 1917). Based on the cities where these exhibitions were articulated, it is clear that Meštrović's immediate point of interest was the Old Continent. Despite the fact that this part of the world was going through an extremely difficult period of geopolitical reconfigurations, accompanied by numerous human and material losses, demanding "sculpture" exhibitions marked by Meštrović's conspicuous activist nerve - were still being held. This political nerve, already affirmed in Vienna, albeit in a somewhat contained form, became clearly articulated in Rome, and finally in London, as it became completely attuned with the artist's participation in the Yugoslav Committee.

Thus far, there were no attempts to use quantitative data analysis for examining Ivan Meštrović's specific period of life, or his life in its entirety, nor was there an attempt made to analyse his reception through such a prism (Tablel). Therefore, 1500 bibliographic units, which include various published materials that contributed to the dissemination of news about Ivan Meštrović and his art during the 1910s, were gathered in one place. Among such mate- ials are exhibition catalogues, pamphlets, and expert texts in specialized magazines, published books, or book chapters, critical articles and reviews in daily, weekly, bi-weekly and monthly journals.

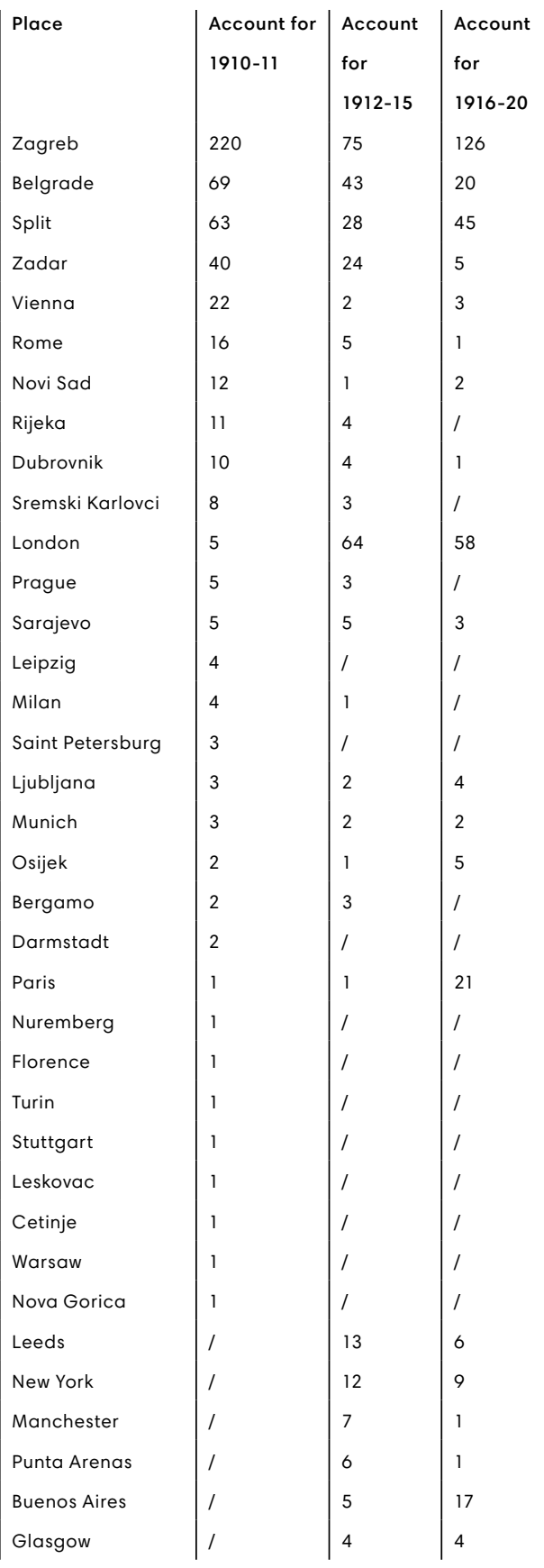

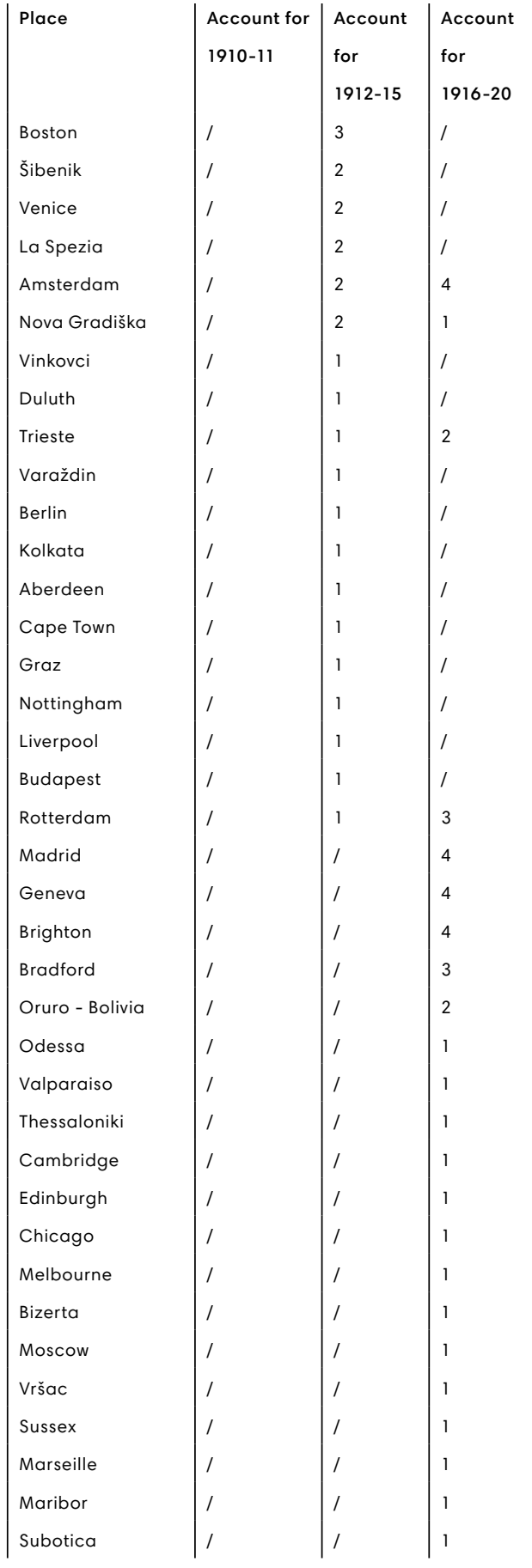

Table 1. Number of articles on Ivan Meštrović published between 1910 and 1920, and ordered according the location of the source publication
Several data sources were crucial in conducting the analysis. First of all, an important source was the Građa za bibliografiju Ivana Meštrovića od 1899. do 1993. [Iva Meštrović's bibliography materials from 1988 to 1933], which holds an extremely high number of the processed biblio graphic units. ${ }^{83}$ However, as valuable as that bibliographic unit is, it is by no mean sufficient for conducting a more comprehensive analysis. Therefore, it needed to be complemented by materials collected during several years of fieldwork and re search in numerous cities, such as London, Leeds, Los Angeles, Prague, Venice, Rome Zagreb, and Belgrade. ${ }^{84} \mathrm{~A}$ six-month stay in the USA and research in their archive and museum institutions, as well as public libraries, must also be added to the list. 85 The newly collected bibliographic units, with the focus on the 1910-1920 period under scrutiny, significantly expanded the lis

83 Jasna Ivančić and Sanja Kreković-

Štefanović, eds., Građa za bibliografiju Ivana Meštrovića od 1899. do 1993. (Zagreb: Fundacija Ivana Meštrovića, Nacionalna i sveučilišna biblioteka, 1993).

84 Archival materials used in this research are stored in the following institutions: Henry Moore Archive, Leeds, Malvina Hoffman Archive, Getty Research Institute, Los Angeles, National Art Library Archive, Victoria \& Albert Museum, London, Archives of Yugoslavia, Belgrade, Archivio storico delle arti contemporanee Venice, Archivio Signorelli, Fondazione

Giorgio Cini, Venice, National Galery, Prague, Galleria Nazionale d'Arte Moderna e Contemporanea, Rome, Archive of Fine Arts - HAZU, Zagreb.

85 Fulbright Schoolar Programme: Dalibor Prančević, "Ivan Meštrović and the Anglophone Cultures (Example of Crosscutting of Various Cultural, Historic and Artistic Experiences", February - July 2018 (Syracuse University). 
of texts published about Ivan Meštrović's artistic activities, as well as about his life. Furthermore, Duško Kečkmet's unpublished manuscript, Ivan Meštrović: Bibliografija, was used as an important source which contributed greatly to this analysis. ${ }^{86}$

However, the aim of this analysis is not to provide an exhaustive interpretation of Ivan Meštrović's individual exhibition projects. Rather, it is to take note of and try to interpret certain interesting moments found through the application of procedures that differ from the traditionally established procedures in art history practice. This includes the use of digital tools which can set in motion an inert assembly of data to recognize new discourse platforms which enable us to examine one artist's oeuvre or life trajectory.

For instance, it is interesting to examine where the largest frequency of texts on Ivan Meštrović, during 1910 and 1911, can be noted (Map. 1): Zagreb (220), Belgrade (69), Split (63) and Zadar (40). Unsurprisingly, Zagreb takes precedence, since there were two exhibitions held in that city in 1910, where Ivan Meštrović became synonymous with artistic-political expression. Regardless, the numbers related solely to his name are truly impressive, which speaks volumes about the propulsive nature of the artist who, at that time, had not even turned thirty. His artistic talent was unquestionable, which can be attested by the fact that he had already exhibited his work in important exhibitions, and received positive reviews. Even Auguste Rodin, himself, spoke highly of him. ${ }^{87}$ Nevertheless, all of

86 Duško Kečkemet, Ivan Meštrović:

Bibliografija 1899 -2002 (Split: Filozofski fakultet u Splitu, Duško Kečkemet, forthcoming)

87 See more in: Barbara Vujanović, "Doticaji umjetnika: Auguste Rodin i Ivan Meštrović," in Rodin u Meštrovićevu configurations present uring the 1910s, in the period of consolidating the "New Course" policy, that is, the political programme whose primary goal was to improve the constitutional sta(n) Austro-Hungarian Empire, i.e., their unification (Banovina of Croatia and Dalmatia). This policy was promoted by Ante Trumbić, Frano Supilo, and Pero Čingrija, all of whom Meštrović knew personally, maintained correspondence with (especially later on), and even made portraits of some of them. That policy, through the adoption of two documents, the Zadar and Rijeka Resolutions, enacted the prerogative of forming a Croatian-Serbian alliance, that is, the founding of the Coalition in 1906 at first with Supilo at the head, and after he stepped down, with Svetozar Pribičević. All of these names are present in Meštrović's correspondence, and they constitute important elements of his later "political" networking. The conversion of the data into a digital medium, and its processing, in fact, point to the overlapping of the crucial ocations of Meštrović's critical fortune with locations of important political activities, with the ramifications thereof becoming most pronounced during the 1910s: Zagreb-Belgrade-Split-Zadar.

Nevertheless, the appearance of Saint Petersburg on the map of Meštrović's reception during these early years is definitely surprising. It should be mentioned that the number of published texts is not large, but it is more than sufficient to raise the question of Ivan Meštrović's presence within the artistic discourse of that city, but also Russia in general. Most of the texts refer to Meštro-

Zagrebu, eds. Jasminka Poklečki Stošić and Barbara Vujanović (Zagreb: Umjetnički paviljon, Muzeji Ivana Meštrovića, 2015), 60-84
Map 1 . (data processed using Tablea software) 

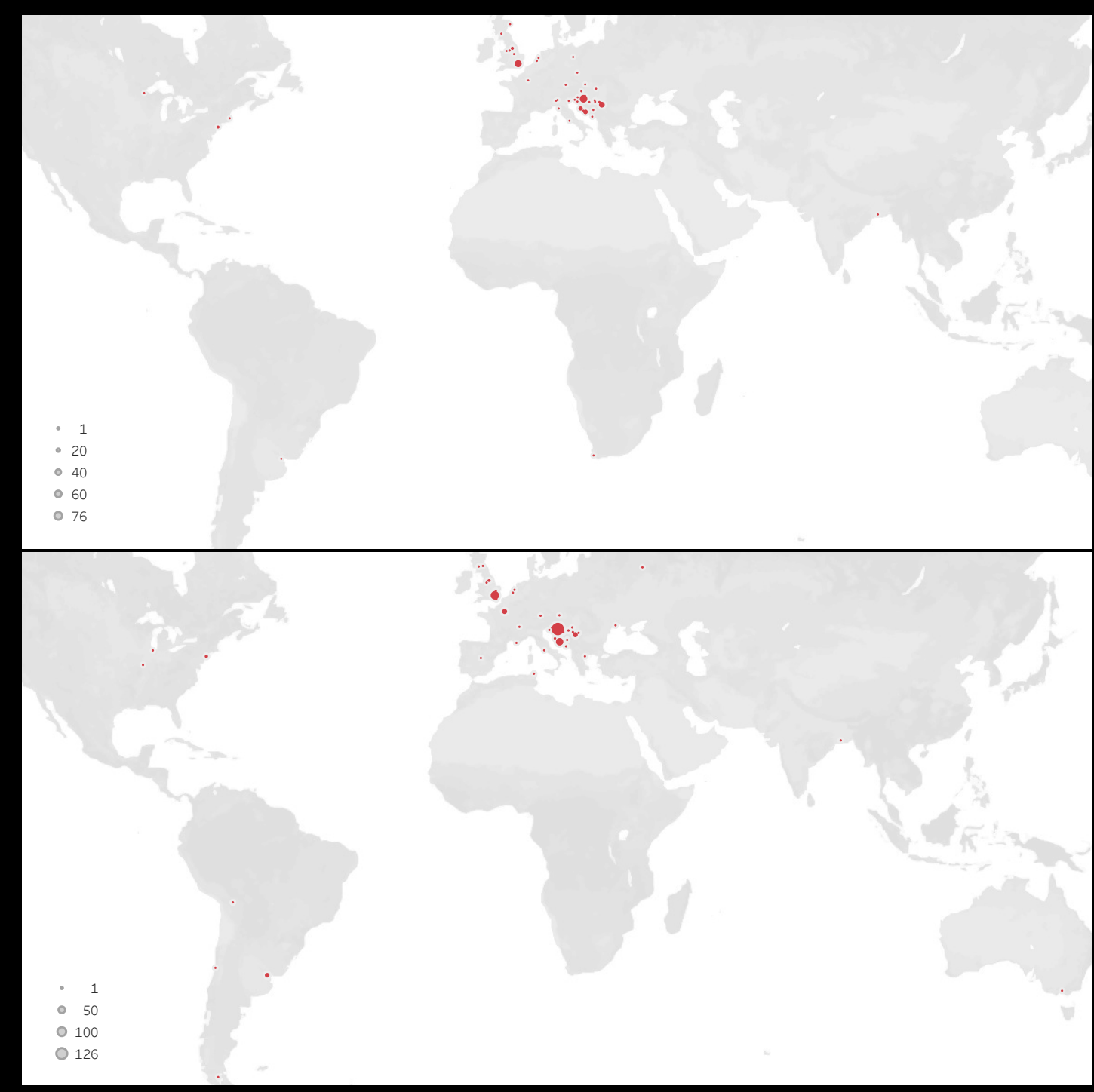

Map 2

Spatial distribution of articles on Ivan Meštrović published between 1912 and 1915 (data processed using Tableau software)

Map 3

Spatial distribution of articles on Ivan Meštrović published between 1916 and 1920

(data processed using Tableau software) vić's success at the Rome exhibition. ${ }^{88}$ It is especially interesting that one of the texts was written by Alexandre Nikolayevich Benois, Russian artist and art critic known for his close collaboration with Sergei Diaghilev. The domestic public also took notice of that text and the "Russian opinion" on Meštrović. ${ }^{89}$ Indeed, Ivan Meštrović's connections with the Russian cultural circle of that time have not been particularly noted up to this point. A digital map, of sorts, rais es the question on the possibility to analys and reconstruct these connections, while this text will later provide a "rough" sketch of their possible physiognomy. The following two maps clearly show the dissemination of information on Meštrović's work and his engagement as a sculptor, after successful exhibitions in Europe (Map 2 and Map 3). After his successful London exhibition, he also toured other British cities, thus frequent written mentions of the artist were to be expected in the British cultural circle. How ever, it is relatively surprising that there is a certain number of texts from South America that also referred to the artist. It is in triguing that Meštrović also received letters from South America, primarily due to the economically motivated immigration wave from Croatia, starting at the end of the 19th century, but also due to the more recen immigration waves. Immigrant communitie disseminated information about cultura events and political initiatives, especially about the work of the Yugoslav Committee.

88 Yakov Tugehhol'd, "0 Meštrovićevim djelima na Rimskoj izložbi," Apollon (1911); Alexandre Nikolajevič Benois, "0 Meštroviću povodom Međunarodne izložbe u Rimu", Ryech (1911)

89 "Rus o Meštroviću", Srbobran, 4 April 1911; "Ruski sud o Meštroviću", Brankovo kolo, 13 October 1911; "Ruski glas o Meštroviću", Narodni list, 9 September 1911 it published texts about Meštrović and his European exhibitions. The texts were written by Meštrović himself, his friend and English critic, James Bone, and the prominent members of the Yugoslav Committee, Josip Jedlowsky, Ljubo Leontić, and Marjan Marjanović. Naturally, this geographic distribu tion of critical texts is also accompanied by the respective Meštrović's correspondence. For example, whereas Ljubo Leontić wrote very favourably to Meštrović about his life in South America - Antofagasta in Chile, and Buenos Aires in Argentina - expressing his opinions on the Yugoslav question and th work of the Committee, Marjanović was not overly satisfied with his stay in Valparaíso in Chile, where he lived in 1918.90

Furthermore, the maps show that Meštrović's success was recorded even in India, namely, Kolkata. The direct connections between the artist and India have not yet been es tablished - at least not in that period - but certain individuals linked to Meštrović were in direct contact with the Indian cultural milieu. In that regard, we should mention Ananda Coomaraswamy, whose efforts in promoting Indian art might have had a certain morphological effect on Meštrović's art in 1917 or 1918, which definitely requires further study and comparative analysis. Also worth men tioning is Abdullah Yusuf Ali, from Bombay by birth and part of the Islamic tradition, who published a booklet on Meštrović's art in London, in 1916, and who exchanged correspondence with and even met with the artis in London and Paris.

Therefore, such a geographical dispersion of texts about Meštrović, and their visualization, actually prompt the need to reconstruct Meštrović's presence in certain cul-

90 Meštrović's Correspondence: Leontić Ljubo, ident. 508 and Marjanović, Milan, ident. 542 (AAM, Zg, Pup) 
tures or continents, which, in large part, has not yet been addressed or emphasized in the interpretations of the artist's work or life. This also applies to the African continent where certain texts were also published, but which cannot be further explicated at this point. However, with additional insights into the issue of the modernist heritage in Africa, this predicament is sure to change.

UNREALISED EXHIBITIONS IN RUSSIA AND AMERICA

The data on the reception of Ivan Meštrović's work in Russia, i.e., Saint Petersburg were noted as early as 1911, and result from Meštrović's intense exhibition activities and success at the International Fine Arts Exhibition in Rome. The connections with Rus sian culture are not one-sided, and they were most certainly mediated by Signorelli's social salon in Rome because Olga was of Russian origin and many important cultural protagonists from Russia gathered in her Salon. Furthermore, it is important to mention Meštrović's exchange of letters with writer and journalist, Alexander Amfiteatrov, who had connections with Saint Petersburg and Sergei Diaghilev.

However, the initiative for organizing an exhibition in Saint Petersburg was undertake at a somewhat later date in 1916. We should also mention a very interesting letter whic was sent to Meštrović from Odessa, on 29 March 1916, by writer Josip Kosor (III. 4). Kosor had been truly excited that he would see Meštrović at the exhibition in Saint $\mathrm{Pe}$ tersburg, and he informed Maksim Gorki of that occasion, so he expressed regret over postponing the exhibition till autumn. As he notes, he was asked to put off the publishing of his essay until the beginning of autumn

91 Meštrović's Correspondence: letter from Josip Kosor to Ivan Meštrović, ident. 461 A1 (AAM, Zg, Pup) when the exhibition would open. However, he already had the text translated into Russian and sent it to Gorki in Saint Petersburg for his chronicle. Kosor wrote to Meštrović that the ambassador of the Kingdom of Serbia in Russia, Miroslav Spalajković, would certainly support Meštrović's exhibition and help in its realization.

Meštrović would soon receive a letter from university professor Pavle Popović, a renowned philologist and a politically active member of the Yugoslav Committee, urging him to cancel the exhibition in Russia, and reorient to Paris, due to financial obstacles. ${ }^{92}$ This turn of events cannot really be explained by one specific event, but it might have resulted from a discussion that certain political protagonists had in relation to the question of the South Slavic unification, which certain individuals in Russia did not support.93 On 15 June 1916, Miroslav Spalajković sent an official telegraph to Meštrović, informing the artist that the committee in Saint Petersburg can only provide moral and not financial support for his exhibition. He furthermore suggested that the organisation of the exhibition be funded by the Yugoslav Committee or the Government of the Kingdom of Serbia. ${ }^{94}$

During May 1916, Ivan Meštrović sent letters to Ante Trumbić, inquiring about the exhibition. ${ }^{95}$ Namely, he made all the necessary arrangements for the transport of the artworks, and it was his intention to also send new artworks, religious in character, which he created in Geneva. He pointed out that

92 Meštrović's Correspondence: Popović, Pavle, ident. 698 (AAM, Zg, Pup).

93 Meštrović, Uspomene na političke ljude i događaje, 39-40.

94 Meštrović's Correspondence:

Spalajković, Miroslav, ident. 799 (AAM, Zg, Pup).

95 Meštrović's Correspondence: Trumbić, Ante, ident. 868 (AAM, Zg, Pup)

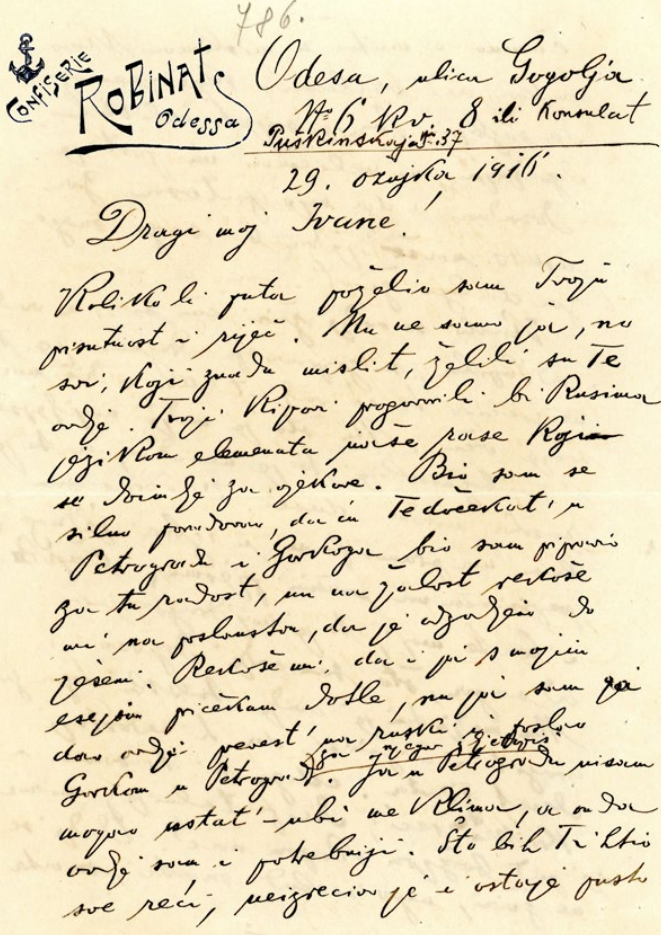

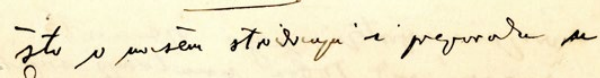

rome:

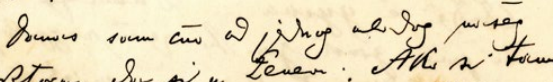

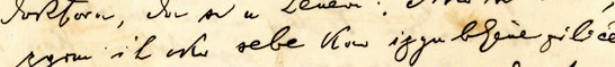

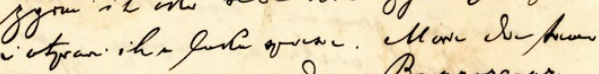
gnisur ving dour groh. Baprosecur,

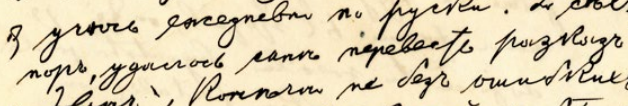

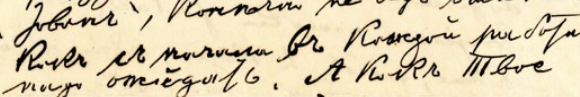

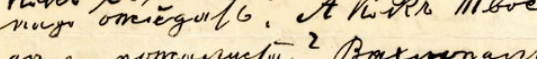

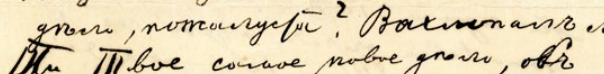
hotpurany of zaroct conguarto a

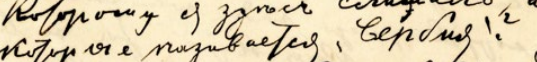

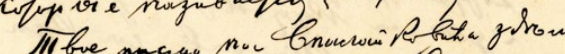

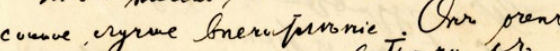

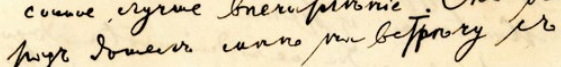

puge boraen

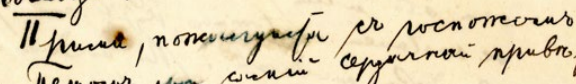

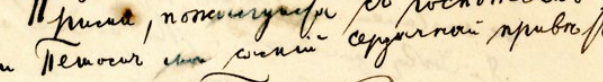
IIfou tocopro
III. 4

The letter of Josip Kosor to Ivan Meštrović, Odessa, dated 29 March. 1916. (Letter from the Correspondence collection of Atelier Meštrovic Archives, Zagreb; ident. 461 Al, courtesy of Mate Meštrović) 
was an exceptionally successful manager who could bring Meštrović not only moral but also material success in America. This exhibition was a collaborative project on a higher political level as well. Namely, at the beginning of November, Milenko Vesnić ent a telegram to Groth from Paris, informing her that the prince regent, Alexander Karađorđević, agreed to be the patron of the exhibition. Groth informed Meštrović about this, providing a lot of interesting information in the letter sent on 16 December 1916 (III. 5). ${ }^{101}$ Namely, Christian Brinton was mentioned in the letter as the person in charge of the catalogue, and Cornelia age for museums outside New York. Also of interest is the naming of prominent New York cultural figures who promised initial inancial support. Among those mentioned was the wife of Harry Payne Whitney, Gertrude Vanderbilt Whitney, a well-known patron of the arts and a sculptor herself, future ounder of the famous New York museum, Henry Clay Frick, an industrialist, patron of the arts, and future founder of the Frick Collection in New York, Thomas Fortune Ryan, industrialist and businessman, and Otto Hermann Khan, a banker, philanthropist and patron of the arts. Of course, the key figure was the scientist Mihajlo Pupin. However, the war and the precarious transport conditions interrupted the organisation f the exhibition and it was postponed until it was finally scrapped. Throughout the correspondence, it is interesting to take note of Catherine D. Groth's resolute business attitude, since Meštrović's former associates had certain complaints about her, especially Božo Banac, who was in charge of the transport of the artworks. ${ }^{102}$ This is made

01 Meštrović's Correspondence: letter from Catherine D. Groth to Ivan Meštrović ident. 345 A7 (AAM, Zg, Pup)

102 Meštrović's Correspondence: Banac, Božo, ident. 94 (AAM, Zg, Pup). sent to the sculptor , commented, among other things, that the names Groth mentioned were truly the wealthiest people in New York, but that he should be wary because she would demand a hefty percentage. It seems that things got more complicated over the following months, leading Milan Ćurčin to write to Ivan Meštrović on 5 March 1917, saying he did not think that there was any conspiracy on the part of Groth, since she still wanted to manage the entire project, but that it was obvious that she was also, naturally, workng in her own favour. ${ }^{103} \mathrm{He}$ stated that she actually perceived everything as a business arrangement. Shortly afterwards, in March, all the packaged artworks were returned to London, supposedly because trans-Atlantic ships were in danger of being torpedoed. Looking at the geographic distribution maps of texts about lvan Mestrovic, it is interesting to note his gravitation towards the western hemisphere, which would, in a way, ensure his affirmation in America in the following period, attested by his solo-exhibitions held - first in the Brooklyn Museum, and then in other American cities - and the fact that he was commissioned to create a sculpture of the Equestrian Indians by the city of Chicago. On these occasions, Cornelia Sage and Malvina Hoffman proved to be very apt "managers". It is especially ineresting to note that women were the ones who undertook much of the initiative and activity in organizing Meštrović's exhibitions in America, as well as in his promotion in that cultural space.

03 Meštrović's Correspondence: Ćurčin, Milan, ident. 234 (AAM, Zg, Pup). 
grebu 1911. od 1. svibnja do 1. lipnja. (Exhibition cat-

Kraševac, Irena. Ivan Meštrović i secesija. Beč München - Prag: 1900.-1910. Zagreb: Institut za povijest umjetnosti, and Fundacija Ivana Meštrovića, 2002.

Kraševac, Irena, and Željka Tonković. "Umjetničko umrežavanje putem izložaba u razdoblju rane moderne - sudjelovanje hrvatskih umjetnika na međunarodnim izložbama od 1891. do 1900. godine". Radovi Instituta za povijest umjetnosti, no. 40 (2016): 203-17.

Kraševac, Irena, and Petra Vugrinec, eds. Izazov moderne: Zagreb - Beč oko 1900, exhibition catalogue. Zagreb: Galerija Klovićevi dvori, 2017.

Kraševac, Irena, ed., 150 godina Hrvatskog društva likovnih umjetnika. Umjetnost $\mathrm{i}$ institucija. Zagreb: $\mathrm{Hr}-$ vatsko društvo likovnih umjetnika, Institut za povijest umjetnosti, 2018.

Kršnjavi, Izidor. "Druga izložba Društva hrvatskih umjetnika, I. Slovenski slikari," Narodne novine, December 31, 1900.

Krzysztofowicz-Kozakowska, Stefania, and Piotr Mizia. "Sztuka-Wiener Secession-Mánes. The central European Art Triangle," Artibus et Historiae, vol. 27, no. 53 (2006): 217-259.

Maruševski, Olga. Društvo umjetnosti 1868.-1879.-1941. Zagreb: Društvo povjesničara umjetnosti Hrvatske, 2004.

Milčinović, Andrija. “Umjetnička izložba," Savremenik, no. 8 (1911): 526-529.

Rollig, Stella, Irena Kraševac, and Petra Vugrinec, eds. The Challenge of Modernism: Vienna and Zagreb eds. The Challenge of Modernism: Vienna and Zagreb
around 1900, exhibition catalogue. Vienna: Belvedere,

Secessioni Europee. Monaco, Vienna, Praga, Roma, Palazzo Roverella, exhibition catalogue. Rovigo: Silvana Editoriale, 2017.

Wilhelmi, Christoph. Künstlergruppen in Deutschland, Österreich und der Schweiz seit 1900. Ein Handbuch, Stuttgart: Dr. Ernst Hauswedell \& Co., 1996.

Žerovc, Beti. Slovenski impresionisti. Ljubljana: Mladinska knjiga, 2013.

\section{ONLINE SOURCES}

Belvedere. "HAGENBUND. Ein europäisches Netzwerk der Moderne (1900 bis 1938)". Accessed January 5, 2019. http://tools.fas.at/hagenbund/exhibition.html
ArtHist Austria. "Exhibitions of Modern European Paintarthist.at/projektdetail/exhibitions-of-modern-eur pean-painting-1905-15.html

DALIBOR PRANČEVIĆ

Between Art Nouveau and the Avant-Garde: The Personal (Ego) Network of Ivan Meštrović and the Map of Critical Reception of His Work during the 1910s pp. 38-62

"Rus o Meštroviću". Srbobran April 4, 1911.

"Ruski glas o Meštroviću". Narodni list September 9, 1911.

"Ruski sud o Meštroviću". Brankovo kolo October 13, 1911.

Bulimbašić, Sandi. Društvo hrvatskih umjetnika "Medulić (1908.-1919.). Zagreb: Društvo povjesničara umjetnosti Hrvatske, 2016.

Clegg, Elizabeth. "Meštrović, England and the Great War." The Burlington Magazine, no. 144, (December 2002) 740-751.

Ivančić, Jasna, and Sanja Kreković-Štefanović, eds. Građa za bibliografiju Ivana Meštrovića od 1899. do 1993. Zagreb: Fundacija Ivana Meštrovića, Nacionalna i sveučilišna biblioteka, 1993.

Kečkemet, Duško. Život Ivana Meštrovića (1883.-1962. 2002.), Vol. I and Vol. II. Zagreb: Školska knjiga, 2009.

Kečkemet, Duško. Ivan Meštrović: Bibliografija 1899-2002. Split: Filozofski fakultet u Splitu, Duško Kečkemet, 2017. knjiga je u tisku.

Kraševac, Irena. Ivan Meštrović i secesija. Beč - München - Prag: 1900.-1910. Zagreb: Institut za povijest umjetnosti, and Fundacija Ivana Meštrovića, 2002.

Machiedo Mladinić, Norka. "Prilog proučavanju djelovanja Ivana Meštrovića u Jugoslavenskom odboru." Časopis za suvremenu povijest, vol. 39, no. 1 (June 2007): 133-156.

Meštrović, Ivan. Uspomene na političke ljude i događaje. Zagreb: Matica hrvatska, 1969.

Milačić, Karmen. Talijanska pisma Ivanu Meštroviću 1911 1921. Zagreb: Globus, 1987.

Prančević, Dalibor. "Odjek Ivana Meštrovića u Velikoj Britaniji nakon izložbe u Victoria \& Albert Museumu". In Zbornik II. kongresa hrvatskih povjesničara umjetnosti, Z5 403 . Zagreb: Institut za povjest umjenc
Prančević, Dalibor. "Sculpture by Ivan Meštrović at the Grafton Galleries in 1917: critical and social contexts." Sculpture Journal, vol. 25, no. 2 (2016): 177-192.

Prančević, Dalibor. Ivan Meštrović i kultura modernizma: ekspresionizam i Art déco. Split: Filozofski fakultet u Splitu, Muzeji Ivana Meštrovića, 2017.

Scott, John. Social Network Analysis: A Handbook. London: Sage Publications, 2000.

Vujanović, Barbara. "Doticaji umjetnika: Auguste Rodin i Ivan Meštrović". In Rodin u Meštrovićevu Zagrebu, edited by Jasminka Poklečki Stošić and Barbara Vujanović, 60-84. Zagreb: Umjetnički paviljon, Muzeji Ivana Meštrovića, 2015

\section{ARCHIVAL SOURCES}

Atelier Meštrović Archives, Letters collection, Zagreb.

University of Notre Dame Archives, Notre Dame, Indian 46556, Ivan Meštrović Papers, 1924- 1962.

\section{ONLINE SOURCES}

Bentkowska-Kafel, Ana. "Debating Digital Art History. International Journal for Digital Art History, no. 1 (2015) 50-64. https://doi.org/10.11588/dah.2015.1.21634b

TAMARA BJAŽIĆ KLARIN, NIKOLA BOJIĆ

CIAM Network Visualisation - Detecting Ideological Ruptures in the CIAM Discourse pp. 64-82

Anon., "Architecture et urbanisme en U.R.S.S." L'Architecture d'Aujourd'hui, no. 8 (1932): 49-96.

Bjažić Klarin, Tamara. Ernest Weissmann: društveno angažirana arhitektura, 1926 - 1939/Ernest Weissman Socially Engaged Architecture, 1926-1939. Zagreb: Hrvatska akademija znanosti i umjetnosti, Hrvatski muze arhitekture, 2015.

Bjažić Klarin, Tamara. "CIAM Networking - Internationa Congress of Modern Architecture and Croatian arch tects in the 1950s." Život umjetnosti, no. १९ (2016), 40-57. tectsin the 1950." Zivot umje science?" Papers of the Regional Science Association science?" Papers
no. 1 (1970): 6-21.

Huber, Benedikt. Die Stadt des Neuen Bauens. Projekte und Theorien von Hans Schmidt. Zürich: gta ETH, 1993.

Mumford, Eric. The CIAM discourse on urbanism, 1928 1960. Cambridge, Mass.: MIT Press, 2000.

Risselada, Max, and Dirk van den Heuvel, eds. Team 